\title{
The Anxiety Levels of the Parents of Premature Infants and Related Factors
}

\section{Prematüre Bebeği Olan Anne ve Babaların Kaygı Düzeyleri ve llișkili Faktörler}

\author{
Raziye Çelen, Fatma Taş Arslan \\ Selçuk University Faculty of Health Sciences, Department of Pediatric Nursing, Konya, Turkey
}

\begin{abstract}
Aim: The aim was to determine the anxiety levels of parents with premature infants and related factors.

Materials and Methods: This comparative descriptive study was conducted in the neonatal intensive care unit of four hospitals located in Konya, Turkey between March and April 2012 with the parents (n=194; 97 mothers, 97 fathers) of premature infants who were 32-37 weeks gestational. Data were collected using Parents and Infant Information Form prepared by the researchers, and State-Trait Anxiety Inventory Scale.

Results: The mean state anxiety scores of the mothers and fathers were similar ( $p>0.05$ ). The mothers had higher mean trait anxiety scores compared to the fathers and this difference was found to be statistically significant $(p<0.05)$.

Conclusion: It was observed that parents with premature infants experienced mild anxiety.

Keywords: Anxiety, parents, premature, related factors, State-Trait Anxiety Inventory
\end{abstract}

\section{öz}

Amaç: Çalışma prematüre bebeği olan anne ve babaların kaygı düzeyleri ve ilişkili faktörleri belirlemek amacıyla yapıldı.

Gereç ve Yöntemler: Karşıșştırmalı tanımlayıcı çalışma, Konya ili kent merkezinde yer alan, yenidoğan yoğun bakım ünitesi bulunan dört hastanede, Mart-Nisan 2012 tarihleri arasında yapıldı. Örneklem grubunu 97 prematüre bebeğin anne ve babası oluşturdu $(n=194)$. Verilerin toplanmasında araştırmacılar tarafindan oluşturulan Ebeveyn ve Bebek Bilgi Formu ve Durumluk-Sürekli Kaygı Ölçeği kullanıldı.

Bulgular: Annelerin ve babaların durumluk kaygı puan ortalamaları benzer olduğu saptandı $(p>0,05)$. Annelerin sürekli kaygı puan ortalamalarının babalara göre yüksek olduğu ve bu farkın istatistiksel olarak anlamlı olduğu bulundu $(p<0,05)$.

Sonuç: Prematüre bebeği olan anne ve babaların hafif düzeyde kaygı yaşadıkları görüldü.

Anahtar Kelimeler: Anksiyete, anne-baba, prematüre, ilişkili faktörler, Durumluk-Sürekli Kaygı Ölçeği

Parents who are not psychologically ready for a preterm delivery, go through high levels of anxiety (5-7). The fact that a premature infant has more common health problems also affects the anxiety levels of the parents. Factors such as family and infant characteristics, the severity of the infant's health condition, parent-infant relationship are related to the outcome of premature infants (8). The mother and father
Premature delivery is a major critical problem that causes high perinatal morbidity and mortality rates (1-3). The World Health Organization reports that one of every 10 births is premature (2). In Turkey, the rate of premature delivery is reported to be $12 \%(4)$.

\section{Address for Correspondence/Yazıșma Adresi}

Raziye Çelen MD, Selçuk University Faculty of Health Sciences, Department of Pediatric Nursing, Konya, Turkey Phone: +903322233546 E-mail: rturgut42@gmail.com

This study was presented orally in the $5^{\text {th }}$ Congress of the European Academy of Pediatric Societies on 17-21 October 2014, in Barcelona, Spain.

Received/Geliş tarihi: 24.01.2017 Accepted/Kabul tarihi: 20.04.2017

${ }^{\circ}$ Copyright 2017 by Ege University and Ege Children's Foundation

The Journal of Pediatric Research, published by Galenos Yayınevi. 
must adapt to their new roles in providing a safe environment for and taking care of their infant. In this process, they should learn how to communicate with their infant as well as how to manage the baby's problems. Also social support should be provided for both the mothers and fathers to prevent stress and anxiety during this period $(9,10)$.

The parents of infants in neonatal intensive care units (NICUs) may feel high anxiety due to the severity of their infant's illness, the ambiance of the unit, and the psychosocial feeling of seperation (9). Previous studies show that the mothers of premature infants in the NICU may have a mild level $(11,12)$, medium level $(13,14)$ and high level $(15,16)$ of anxiety.

Most of the studies focus on maternal stress in general; there is even less information about a father's long-term adaptation $(9,17,18)$. However, the family should be evaluated as a whole including both parents. More studies are needed as the number of premature deliveries is high and this group of babies require special care. Studies conducted in this field shall make positive contributions to creating awareness among parents and nurses of newborns, and create an important literature specific to this field.

The aim of our study was to determine the anxiety levels of the parents of premature infants. We also aimed to determine the factors that could impact anxiety on these parents.

\section{Materials and Methods}

\section{Setting}

This comparative descriptive study was conducted in the $\mathrm{NICU}$ of four hospitals located in Konya between March and April 2012.

\section{Sample}

The table presented in "determine sample size of descriptive studies with dependent variables" (19) was used to determine the sample size of the study, and we used the rate reported by Özyazıcıoğlu and Tüfekci (20) (52.88 \pm 10.18$)$. The aim was to determine the score to be taken from the state trait anxiety scale within $95 \%$ confidence level and \pm 2 point confidence interval. Accordingly, the total width was taken as 4 points ( 2 points above and 2 points below). In the calculation standardized range width= the total width/ standard deviation (SD) $(4 / 10.18=0.37$ approximately 0.40$)$ was found (19). The calculated sample size in each group was 97 (97 mothers, 97 fathers). Considering 10\% drop out rate the study sample size was set to 107 . Three fathers among these did not agree to join the study for confidentiality reasons, and seven parents did not complete the questionnaire.

Inclusion criterion was to be the mother and father of a premature infant of 32-37 weeks of gestational age, hospitalized at the NICU, and planned to be discharged from the NICU in 2-3 days. All the parents were required to sign the informed consent.
Exclusion criteria were the infants diagnosed with a genetic disorder and/or major congenital malformations, and parents who had a previously hospitalized premature infant younger than 32 weeks of gestational age.

\section{Data Collection}

Data were collected from the parents by the researcher via face-to-face interview in a separate room outside the NICU.

\section{Measures}

"Parents and Infant Information Form" and "State-Trait Anxiety Inventory (STAI)" were used.

Parents and Infant Information Form was developed by the researcher (21-23). The form included five questions regarding the socio-demographic characteristics of the parents (age, education level, working status, health insurance, perceived income), 11 questions concerning the mother and the infant (gender, delivery method, gestational week of the mother, postmenstrual age of the infant, diagnosis, interventions implemented to the infants in the postpartum period, feeding methods, number of children, having premature infants previously, birth weights, the hospitalization period of the infants), and the opinions of the parents regarding the care of the premature infant (currently experienced anxiety regarding the infant's care), and 6 questions on the perception of the mothers concerning their adequacy fields in the field of infant care (feeling sufficient for the baby's care, moniliasis care, evaluating respiration, discharge training regarding infant care).

STAI Scale, Spielberger STAI (STAI-I), developed by Spielberger et al. (24) in 1983 and adapted to Turkish by Öner and Le Compte (25) in 1985 was used to assess the anxiety level. This assesses both state anxiety, i.e. current mood; and trait anxiety, i.e. general predisposition towards anxiety. It is a 4-point scale consisting of 40 items. Both scales include 20 items, such as I am worried (state anxiety) and I feel nervous and restless (trait anxiety). Both showed good internal consistency-Cronbach's $\alpha=0.86$ and 0.89. Internal consistency was adequate in this sample (Cronbach's $\alpha=0.92$ and 0.89).

\section{Ethical Considerations}

Before the study was started, Ethical Committee consent was received from Selçuk University Faculty of Medicine in January 2012 (approval number: 2012/01) and the related permissions were obtained from each hospital where the study took place, and from the all parents within the study population.

\section{Statistical Analysis}

Data were analysed using the SPSS version 20 (SPSS; IBM, New York, USA). Normal distribution of dependent variables was evaluated by conducting a normality analysis through Kolmogorov-Smirnov test and it was found that they showed normal distribution. Number, percentage and mean \pm SD were used to determine descriptive data. Independent 
samples $t$ test, Mann-Whitney $U(U)$ tests, and Kruskal-Wallis $(\mathrm{KW})$ and Bonferroni-corrected Mann-Whitney $\mathrm{U}$ (for KW test) were used to determine the differences between groups. $\mathrm{P}<0.05$ value was accepted significant in all the analyses.

\section{Results}

\section{Features of the Parents and Infants}

Mean age of the mothers participating in the study was $26.77 \pm 5.31$ and mean age of the fathers was $30.13 \pm 5.35$. Of the mothers $38.2 \%$ were primary school graduates, $86.6 \%$ were unemployed, $66 \%$ evaluated their monthly income as mediocre, while $37 \%$ of the fathers were primary school graduates, $91.8 \%$ had a wage-earning employment, and $72.2 \%$ evaluated their monthly income as mediocre (Table I). In addition, $87.6 \%$ of the parents had a health insurance, $44.2 \%$ had one child, and $14.4 \%$ previously had a premature infant.

Of the premature infants $52.6 \%$ were born in gestational weeks $35-37,55.7 \%$ were planned to be discharged in gestational weeks $35-37,50.5 \%$ were male, $67 \%$ were born via cesarean section, and $44.3 \%$ were in hospital only because of being premature. While $81.5 \%$ of the infants stayed in an incubator, $76.3 \%$ were fed only with breast milk (Table II). The gestational weeks of the premature infants were $34.51 \pm 1.68$, and their postmenstrual ages were $36.12 \pm 2.01$ weeks. Their birth weights were $2210.03 \pm 568.17$ grams, and postmenstrual weights were $2264.36 \pm 568.72$ grams. Mean hospitalization period of the premature infants was found to

\begin{tabular}{|c|c|c|c|c|}
\hline \multirow[b]{2}{*}{ Characteristics } & \multicolumn{2}{|c|}{ Mothers $(n=97)$} & \multicolumn{2}{|c|}{ Fathers $(n=97)$} \\
\hline & $n$ & $\%$ & $\mathrm{n}$ & $\%$ \\
\hline \multicolumn{5}{|l|}{ Age $^{*}$} \\
\hline $18-24$ years & 38 & 39.2 & 14 & 14.5 \\
\hline $25-31$ years & 39 & 40.2 & 46 & 47.4 \\
\hline 32 and more years & 20 & 20.6 & 37 & 38.1 \\
\hline \multicolumn{5}{|l|}{ Educational levels } \\
\hline Primary school & 37 & 38.2 & 36 & 37.0 \\
\hline Secondary school & 33 & 34.0 & 18 & 18.6 \\
\hline High school & 14 & 14.4 & 25 & 25.8 \\
\hline University & 13 & 13.4 & 18 & 18.6 \\
\hline \multicolumn{5}{|l|}{ Working status } \\
\hline Working & 13 & 13.4 & 89 & 91.8 \\
\hline Not working & 84 & 86.6 & 8 & 8.2 \\
\hline \multicolumn{5}{|l|}{ Perceived income status } \\
\hline Good & 29 & 29.9 & 19 & 19.6 \\
\hline Mediocre & 64 & 66.0 & 70 & 72.2 \\
\hline Low & 4 & 4.1 & 8 & 8.2 \\
\hline
\end{tabular}

be $8.49 \pm 6.66$ days (minimum: 2.00 , maximum: 35.00 )

\section{State-Trait Anxiety Levels of the Parents}

While mean state anxiety score of the mothers was $40.15 \pm 11.25$ (minimum: 20, maximum: 72 ), that of the fathers was $37.32 \pm 10.87$ (minimum: 20 , maximum: 67 ), and this difference was not found to be statistically significant $(t=1.785, p=0.076)$. However, mean trait anxiety score of the mothers was $44.30 \pm 8.98$ (minimum: 26, maximum: 65 ), while that of the fathers was $39.45 \pm 8.58$ (minimum: 20, maximum: 67), and this difference was found to be statistically significant at an advanced level $(t=3.842$, $\mathrm{p}=0.000$ ) (Table III).

\section{Factors Related to the Anxiety Levels of the Parents}

When the anxiety levels were examined according to the socio-demographic features of the parents, no statistically significant difference was found between the mothers' ages, educational levels, employment status, perceived income, number of children, previously having had premature infants,

\begin{tabular}{|c|c|c|}
\hline Characteristics & $\mathrm{n}$ & $\%$ \\
\hline \multicolumn{3}{|l|}{ Gender } \\
\hline Female & 48 & 49.5 \\
\hline Male & 49 & 50.5 \\
\hline \multicolumn{3}{|l|}{ Delivery method } \\
\hline Vaginal & 32 & 33.0 \\
\hline Cesarean & 65 & 67.0 \\
\hline \multicolumn{3}{|l|}{ Gestational age } \\
\hline 32-34 weeks & 46 & 47.4 \\
\hline 35-37 weeks & 51 & 52.6 \\
\hline \multicolumn{3}{|l|}{ Postmenstrual age } \\
\hline 32-34 weeks & 21 & 21.6 \\
\hline 35-37 weeks & 54 & 55.7 \\
\hline 38 weeks and over & 22 & 22.7 \\
\hline \multicolumn{3}{|l|}{ Diagnosis } \\
\hline Premature & 43 & 44.3 \\
\hline Premature + additional problems* & 54 & 55.7 \\
\hline \multicolumn{3}{|c|}{$\begin{array}{l}\text { Interventions implemented to infants in postpartum } \\
\text { period }\end{array}$} \\
\hline Incubator & 79 & 81.5 \\
\hline Cot & 4 & 4.1 \\
\hline Mechanical ventilation & 14 & 14.4 \\
\hline \multicolumn{3}{|l|}{ Feeding methods of infants } \\
\hline Breast milk & 74 & 76.3 \\
\hline Breast milk and formula & 23 & 23.7 \\
\hline
\end{tabular}


and state-trait anxiety mean scores ( $p>0.05)$. No significant difference was found between the fathers' ages, number of children, previously having premature infants, and statetrait anxiety mean scores ( $p>0.05)$. The difference between the education levels and trait anxiety mean scores of the fathers was statistically significant in the study (trait anxiety $K W=11.042 \mathrm{p}=0.012$ ). In the advanced analysis conducted through Bonferroni-corrected Mann-Whitney $U$ test, it was determined that primary school graduate fathers had higher trait anxiety mean scores $(43.33 \pm 8.48)$ compared to high school graduate fathers $(36.32 \pm 7.94)$ and this difference was significant $(p=0.003)$. Trait anxiety mean scores of unemployed fathers $(46.75 \pm 11.25)$ were significantly higher (trait anxiety $U=161.0 p=0.010$ ). Trait anxiety mean scores of

Table III. Comparison of mean anxiety score of the mothers and fathers $(n=194)$

\begin{tabular}{|l|l|l|l|l|}
\hline Status of anxiety & $\begin{array}{l}\text { Mothers } \\
(\mathbf{n = 9 7})\end{array}$ & $\begin{array}{l}\text { Fathers } \\
(\mathbf{n}=\mathbf{9 7})\end{array}$ & \multirow{2}{\mathbf{t}}{} & $\mathbf{p}$ \\
\cline { 2 - 3 } & $\overline{\mathbf{x}} \pm \mathbf{S D}$ & $\overline{\mathbf{x}} \pm \mathbf{S D}$ & & \\
\hline State anxiety & $40.15 \pm 11.25$ & $37.32 \pm 10.87$ & 1.785 & 0.076 \\
\hline Trait anxiety & $44.30 \pm 8.98$ & $39.45 \pm 8.58$ & 3.842 & $\mathbf{0 . 0 0 0}$ \\
\hline SD: Standard deviation \\
\hline
\end{tabular}

the fathers were also significant according to their perceived income status (trait anxiety $\mathrm{KW}=8.300 \mathrm{p}=0.016$ ). In the advanced analysis conducted through Bonferroni-corrected Mann-Whitney $U$ test, it was determined that the fathers who perceived their income levels to be low had significantly higher trait anxiety mean scores than those who perceived their income to be good or mediocre (Table IV).

When anxiety levels of the parents were evaluated according to the features of the premature infants, no significant difference was found between gender, delivery method, gestational age (GA), postmenstrual age (PMA) (trait anxiety mean score), diagnosis, feeding methods, and state and trait mean scores of the parents $(p>0.05)$. However, when the PMA of the infants and state anxiety levels of the mothers were examined, a significant difference was found between the groups ( $K W=7.701 \mathrm{p}=0.021)$. In the advanced analysis performed in order to determine between which groups there was a difference, it was noted that the mothers whose PMA was 38 weeks or more, had significantly higher state anxiety scores than those whose PMA was 35-37 weeks.

When anxiety levels of the parents were assessed according to their current anxiety experience regarding the care of their premature infants, parents who stated they currently experienced anxiety had higher state and trait anxiety mean scores, and this difference was found to

Table IV. Comparison of mean anxiety score by socio-demographic characteristics of the mothers and fathers

\begin{tabular}{|c|c|c|c|c|c|c|}
\hline \multirow[b]{3}{*}{ Characteristics } & \multicolumn{3}{|c|}{ Mothers $(n=97)$} & \multicolumn{3}{|c|}{ Fathers $(n=97)$} \\
\hline & \multirow[b]{2}{*}{$n$} & \multirow{2}{*}{$\begin{array}{l}\text { State anxiety } \\
\overline{\bar{x}} \pm \text { SD }\end{array}$} & \multirow{2}{*}{$\begin{array}{l}\text { Trait anxiety } \\
\bar{x} \pm S D \\
\end{array}$} & \multirow[b]{2}{*}{$\mathbf{n}$} & \multirow{2}{*}{$\begin{array}{l}\text { State anxiety } \\
\bar{x} \pm S D \\
\end{array}$} & \multirow{2}{*}{$\begin{array}{l}\text { Trait anxiety } \\
\bar{x} \pm S D \\
\end{array}$} \\
\hline & & & & & & \\
\hline \multicolumn{7}{|l|}{ Educational levels } \\
\hline Primary school & 37 & $41.24 \pm 11.53$ & $45.22 \pm 10.48$ & 36 & $40.14 \pm 9.73$ & $43.33 \pm 8.48^{\mathrm{a}}$ \\
\hline Secondary school & 33 & $38.94 \pm 11.74$ & $45.33 \pm 9.01$ & 18 & $37.50 \pm 13.46$ & $37.56 \pm 5.85$ \\
\hline High school & 14 & $41.36 \pm 10.75$ & $40.57 \pm 6.47$ & 25 & $33.68 \pm 11.37$ & $36.32 \pm 7.94^{b}$ \\
\hline University & 13 & $38.85 \pm 10.46$ & $43.08 \pm 5.48$ & 18 & $36.56 \pm 8.51$ & $37.94 \pm 9.59$ \\
\hline KW (SD: 3) & & 1.392 & 3.463 & & 6.542 & 11.042 \\
\hline$p$ & & 0.707 & 0.326 & & 0.088 & $0.012(a>b)$ \\
\hline \multicolumn{7}{|l|}{ Working status } \\
\hline Working & 13 & $38.69 \pm 9.83$ & $43.46 \pm 7.04$ & 89 & $36.76 \pm 10.85$ & $38.80 \pm 8.06$ \\
\hline Not working & 84 & $40.38 \pm 11.49$ & $44.43 \pm 9.27$ & 8 & $43.50 \pm 9.78$ & $46.75 \pm 11.25$ \\
\hline U & & 510.5 & 488.0 & & 218.0 & 161.0 \\
\hline$p$ & & 0.707 & 0.539 & & 0.070 & 0.010 \\
\hline \multicolumn{7}{|c|}{ Perceived income status } \\
\hline Good & 29 & $36.97 \pm 9.76$ & $43.41 \pm 7.43$ & 19 & $37.00 \pm 9.79$ & $36.68 \pm 7.49^{\mathrm{a}}$ \\
\hline Mediocre & 64 & $41.02 \pm 11.29$ & $43.92 \pm 9.33$ & 70 & $37.29 \pm 11.29$ & $39.13 \pm 7.83^{b}$ \\
\hline Low* & 4 & - & - & 8 & $38.38 \pm 10.88$ & $48.88 \pm 11.74^{c}$ \\
\hline U & & 735.50 & 870.50 & KW (SD: 2) & 0.119 & 8.300 \\
\hline$p$ & & 0.110 & 0.633 & & 0.942 & $0.016(a<c, b<c)$ \\
\hline
\end{tabular}


be statistically significant (mothers state anxiety $t=3.728$ $\mathrm{p}=0.000$, trait anxiety $\mathrm{t}=2.239 \mathrm{p}=0.027$; fathers state anxiety $t=3.697 p=0.000$, trait anxiety $t=2.436 p=0.017$ ). When anxiety levels of the mothers were evaluated according to their perceptions of regarding their adequacy in the field of care, mothers who did not feel sufficient had higher state and trait anxiety mean scores (state anxiety $46.11 \pm 8.88$, trait anxiety $49.74 \pm 7.24$ ), and this difference was found to be significant in the advanced analysis (state anxiety $U=428.50$ $p=0.004$, trait anxiety $U=405.00 p=0.002$ respectively). In terms of counting and evaluating the infant's respiration, mothers who did not feel adequate had higher state anxiety mean scores, and this difference was found to be statistically significant (state anxiety $\mathrm{t}=-2.233 \mathrm{p}=0.028$ ), whereas the difference between trait anxiety mean scores was not significant ( $p>0.05$ ) (Table V). The difference between the state and trait anxiety mean scores of the mothers in providing moniliasis care for the infant was not statistically significant $(p>0.05)$. Nor was the difference statistically different ( $p>0.05)$ when the mothers' state and trait anxiety mean scores were evaluated according to the hospital discharge training to be received regarding the infant's care.

\section{Discussion}

The study determined that the mothers of premature infants had higher anxiety than their fathers. While the anxiety of the father was more influenced by reasons such as being primary school graduates, unemployment and low income; the anxiety of the mothers was mostly related to infant care.

It was also determined that the mothers included in the study had higher state anxiety mean scores than the fathers ( $p>0.05)$. The trait anxiety levels of the mothers were also higher than those of the fathers and they experienced mild anxiety $(p=0.000)$ (Table III). State anxiety levels of the parents are thought to be changing depending on the momentary behaviors and reactions of their infants. The fact that infants were kept in a safe environment where medical intervention could be provided for 24 hours in case of a problem could have affected the state anxiety levels of parents positively, and the fact that the mothers had higher state anxiety levels than the fathers may be associated with the mothers' being more sensitive to the negative changes in the infants compared to the fathers. The study also determined that the mothers had higher trait anxiety

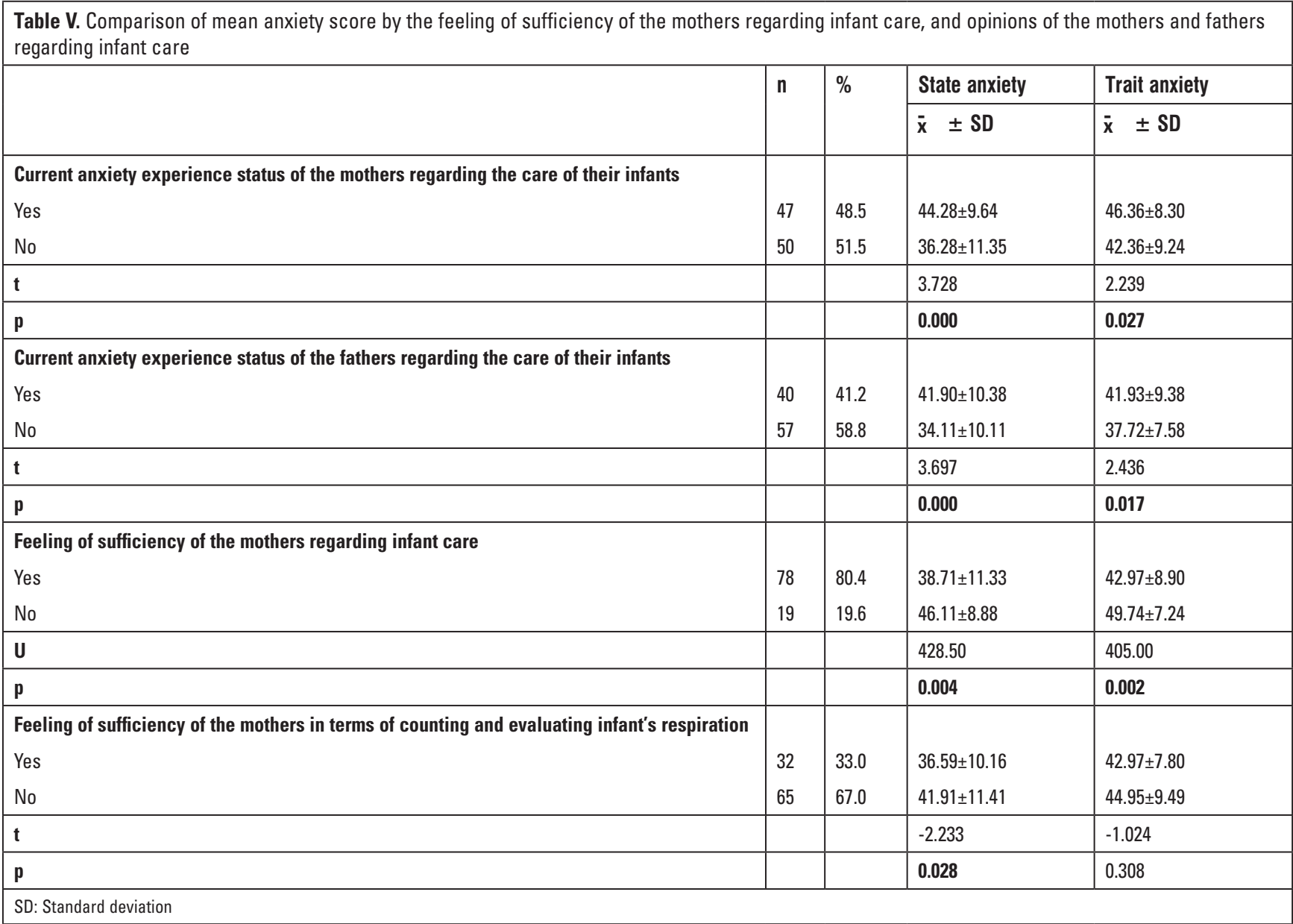


mean scores than the fathers, and mothers experienced a mild anxiety, which may be arising from the uncertainty related to the future, inability to continue infant care at home sufficiently, distress about how to cope with problems after being discharged from hospital, and the fear of losing her infant. Additionally, the mothers' more intense anxiety levels may be explained with the fact that they play the primary role in providing care for their infant and other children, and they are affected more by an unreliable environment. Ghorbani et al. (13) and Gambina et al. (26) showed that anxiety levels in parents of preterm infants were higher than those of term infants. In another study, it was reported that the mothers whose infants stayed in NICU attached to their infants earlier in the postpartum period compared to the fathers, they were more sensitive to negative changes in the infant, and they experienced more fear, depression, feeling of worthlessness and uneasiness (27).

It was seen that only trait anxiety levels of the fathers differed with three variables. In the study, primary school graduate fathers had significantly higher trait anxiety levels $(p=0.012)$ (Table IV). This may be due to the fact that the fathers with lower education levels could not comprehend sufficiently the explanations made regarding the infant's state of health, and they were unsuccessful in developing solutions for problems they encountered. In a study conducted by Miles et al. (28), the mothers with lower education levels were reported to be more worried about the medical conditions of their infants compared to the mothers who had higher education levels.

In this study, fathers who did not work had higher trait anxiety levels compared to those who were working and had mild levels of anxiety $(p=0.010)$ (Table IV). Unemployment of the fathers affected the economical status and welfare of the family directly in a negative way. Fathers with low income levels also had high levels of trait anxiety $(p=0.016)$ (Table IV), which may be related to the anxiety that they may not be able to afford care and medical services for the infant. Additionally, economic status plays an important role in reaching information and meeting requirements.

Mothers whose PMA was 38 or more weeks were found to have higher state anxiety levels than those whose PMA was 35-37 weeks $(p=0.008)$ because premature infants in 35-37 weeks PMA have been in hospital for a longer period and their mothers may have adapted to the situation. They might have had slight anxiety because their infants would be discharged, and they were worried that they were not fully recovered and they did not feel ready for discharge.

It was observed that both the mothers and fathers had different anxiety scores. Parents who stated that they currently experienced anxiety were found to have high state and trait anxiety scores (mothers state anxiety $p=0.000$ trait anxiety $p=0.027$; fathers state anxiety $p=0.000$ trait anxiety $\mathrm{p}=0.017$ ) (Table $\mathrm{V}$ ). Parents may have experienced mild anxiety by thinking that home care would not be sufficient for the infant after being discharged from the hospital, or the infant is too young or they could not be discharged due to some reasons. In a study conducted by Kurnaz and Gençalp (12), no statistically significant difference was found in terms of state anxiety scores between the mothers who stated and those who did not state anxiety before their infants were discharged from the hospital. However, when their state anxiety scores were considered, the mothers stated that they experienced mild anxiety about themselves and their infants (12).

Our results showed that the mothers who did not feel self-sufficient concerning the infant's care had higher anxiety levels compared to those who felt adequate (Table V). A higher anxiety level is expected as a result of the inadequate information had by mothers regarding the infant's care, the fact that almost half of them were primipara, and they did not have a premature infant before. This result reveals the need that mothers should be informed regarding premature infant care.

Mothers who were not sufficient in counting and evaluating respiration had higher state anxiety scores $(p=0.028)$ (Table V), which may be associated with the inadequate information received by the mothers from the medical personnel, and inadequate practices conducted in the clinic with the NICU nurses before being discharged from the hospital.

\section{Study Limitations}

This study has some limitations. First of all, self-report measures like STAI may only indicate the level of anxiety without yielding information about the clinical diagnosis. A further limitation of the study was that the parents of premature infants younger than 32 weeks GA were not included in the study. Finally, we included both first time parents and parents that already had children. So they could have experienced anxiety at different levels.

\section{Conclusion}

Parents of premature infants had mild anxiety, also the mothers had higher trait anxiety levels than the fathers. Being primary school graduates, unemployment, low income affected the anxiety levels of the fathers. Anxiety levels of the mothers whose premature infants were in 38 weeks or more PMA, who did not feel adequate about their infant's care, were found to be higher. State anxiety levels of the mothers who felt inadequate in counting and evaluating the respiration of their infants, were found high. Also current anxiety levels of both the mothers and fathers were high.

Family-centered care practices should be developed to support both the mother/father-infant attachment and parents' empowerment in the care of their infant. Nurses have a vital role in family-centered care and they should apply supportive nursing interventions such as encouraging parents to visit and touch their infants; and explaining the intended use of medical devices. 


\section{Ethics}

Ethics Committee Approval: The study was approved by the Selçuk University Faculty of Medicine Ethics Committee (Approval number: 2012/01, 31.01.2012).

Informed Consent: Consent form was filled out by all participants.

Peer-review: Externally peer-reviewed.

\section{Authorship Contributions}

Concept: R.Ç., FT.A., Design: R.Ç., F.T.A., Data Collection or Processing: R.Ç., Analysis or Interpretation: R.Ç., FT.A., Literature Search: R.Ç., Writing: R.Ç., FT.A.

Conflict of Interest: No conflict of interest was declared by the authors.

Financial Disclosure: This research was financially supported both via oral presentation and the thesis by the Selçuk University Scientific Research Projects Coordinatorship in Konya, Turkey.

\section{References}

1. Şahin E, Tiryaki A. Observing the depression and anxiety levels of the mothers with low-weight-birth preterm infants. Turkiye Klinikleri J Gynecol Obst 2011;21:155-63.

2. WHO Preterm Birth. Available at: http://www.who.int/ mediacentre/factsheets/fs363/en/. Accessed, Feb, 2013.

3. WHO recommendations on interventions to improve preterm birth outcomes 2015. Available at: http://apps.who. int/iris/bitstream/10665/183037/1/9789241508988_eng.pdf. Accessed, Dec, 2016

4. WHO Born Too Soon-The Global Action Report on Preterm Birth. Available at: http://www.who.int/pmnch/media/ news/2012/201204_borntoosoon_countryranking.pdf. Accessed, Nov, 2012.

5. Ionio C, Colombo C, Brazzoduro V, et al. Mothers and fathers in NICU: The impact of preterm birth on parental distress. Eur J Psychol 2016;12:604-21.

6. Çalışır H, Şeker S, Güler F, Anaç TG, Türkmen M. The anxiety levels and needs of infants' parents in a neonatal intensive care unit. Cumhuriyet Üniversitesi Hemşirelik Yüksekokulu Dergisi 2008;12:31-44.

7. Turan T, Başkale H, Öncel G. Determining the psychometric properties of the Turkish version of the nurse-parent support tool and the stress levels of parents of premature infants hospitalized in the neonatal intensive care unit. Clin Nurse Spec 2016;30:1-10.

8. Pierrehumbert B, Nicole A, Muller-Nix C, Forcada-Guex $\mathrm{M}$, Ansermet F. Parental post-traumatic reactions after premature birth: implications for sleeping and eating problems in the infant. Arch Dis Child Fetal Neonatal Ed 2003;88:400-4.

9. Gönülal $D$, Yalaz $M$, Altun-Köroğlu Ö, Kültürsay N. Both parents of neonatal intensive care unit patients are at risk of depression. Turk J Pediatr 2014;56:171-6.

10. Mao Q, Zhu LX, SuXY. A comparison of postnatal depression and related factors between Chinese new mothers and fathers. J Clin Nurs 2011;20:645-52.

11. Carter JD, Mulder RT, Bartram AF, Darlow BA. Infants in a neonatal intensive care unit: Parental response. Arch Dis
Child Fetal Neonatal Ed 2005;90:109-13.

12. Kurnaz E, Gençalp NS. Needs and concerns of mothers with babies in neonatal intensive care units. 4. Uluslararası - 11. Ulusal Hemşirelik Kongresi, Kongre Kitabı, Ankara, 2007.

13. Ghorbani M, Dolatian M, Shams J, Alavi-Majd H. Anxiety, post-traumatic stress disorder and social supports among parents of premature and full-term infants. Iran Red Crescent Med J 2014;16:13461.

14. Padovani FH, Linhares MB, Carvalho AE, Duarte G, Martinez FE. Anxiety and depression symptoms assessment in preterm neonates' mothers during and after hospitalization in neonatal intensive care unit. Rev Bras Psiquiatr 2004;26:251-4

15. Doering LV, Moser DK, Dracup K. Correlates of anxiety, hostility, depression and psychosocial adjustment in parents of NICU infants. Neonatal Netw 2000;19:15-23.

16. Mizrak B, Deniz AO, Acikgoz A. Anxiety levels of mothers with newborns in a neonatal intensive care unit in Turkey. Pak J Med Sci 2015;31:1176-81.

17. Gray PH, Edwards DM, O'Callaghan MJ, Cuskelly M. Parenting stress in mothers of preterm infants during early infancy. Early Hum Dev 2012;88:45-9.

18. Kaaresen PI, Ronning JA, Ulvund SE, DahI LB. A randomized, controlled trial of the effectiveness of an early-intervention program in reducing parenting stress after preterm birth Pediatrics 2006;1189-19.

19. Akgül A. Tıbbi Araştırmalarda Istatistiksel Analiz Teknikleri: SPSS Uygulamaları. 3. baskı, Ankara, Yükseköğretim Kurulu Matbaası, 2005.

20. Özyazıcıoğlu N, Tüfekci GF. Investigation of factors the effects in hopelessness and state-trait anxiety of mothers who cared their baby in neonatal intensive care unit (NICU). Atatürk Üniversitesi Hemşirelik Yüksekokulu Dergisi 2009;12:66-73.

21. Balcı S. Nursing intervention regarding preterm baby care at home and its effect on growth and development of the babies and problem-solving skills of their mothers. PhD, Istanbul Üniversitesi, Istanbul, Turkey, 2006.

22. Uludağ A, Ünlüoğlu I. Determinants of anxiety among mothers of infants in the newborn intensive care unit: role of family physicians on coping with the stressors. Konuralp Tip Dergisi 2012;4:19-26.

23. Yıldız D, Akbayrak N. The effect of education and counseling services given to the primipara mothers during postpartum period on infant care, anxiety level and role of motherhood. Gülhane Tıp Derg 2014;56:36-41

24. Spielberger $C D$, Gorsuch $R L$, Lushene R, Vagg PR, Jacobs GA. Manual for the State-trait Anxiety Inventory. Palo Alto, California, Consulting Psychologists Press, 1983

25. Öner N, Le Compte A. Durumluk Sürekli Kaygı Envanteri El Kitabı. 1. baskı, İstanbul, Boğaziçi Üniversitesi Yayınları, 1985.

26. Gambina I, Soldera G, Benevento B, et al. Postpartum psychosocial distress and late preterm delivery. J Reprod Infant Psyc 2011;29:472-9.

27. Hall EO. Being in an alien world: Danish parents' lived experiences when a newborn or small child is critically ill. Scand J Caring Sc 2005;19:179-85.

28. Miles MS, Burchinal P, Holditch-Davis D, Brunssen S, Wilson SM. Perceptions of stress, worry, and support in Black and White mothers of hospitalized, medically fragile infants. J Pediatr Nurs 2002;17:82-8. 